\title{
EEN BEZOEK AAN DE AROE-BAAI
}

\author{
DOOR \\ J. A. VAN RIJN VAN ALKEMADE, \\ Controleur der le klasse bij het Binnenl. Bestuur.
}

Een bezoek aan de Aroe-baai moge voor den reiziger al niet aantrekkelijk zijn door belangrijke gebeurtenissen welke er thans plaats vinden, noch hem die aangename gewaarwordingen schenken welke men bij het aanschouwen van bekoorlijke natuurtafreelen in een goed bevolkt en welvarend land ondervindt, het neemt niet weg dat een tocht naar dit gedeelte van Sumatra's Oostkust ook hare belangrijke zijde heeft, zij 't dan ook dat ons hier slechts herinneringen uit een geschiedkundig verleden kunnen boeien en een stille, eenvoudige, soms droefgeestige natuur een niet licht te vergeten indruk achterlaat.

De bovenbedoelde streek, waar eens de zetel moet zijn geweest van een rijk, dat in aanzien en macht kon wedijveren met de toenmalige rijken Pasei en Malakka, behoort tot die gedeelten van den Indischen Archipel, welke dikwerf door personen worden bezocht, doch die slechts weinig of geen belangstelling van den kant der bezoekers mochten opwekken.

Die weinige belangstelling - meestal een gevolg van een al te oppervlakkige kennisneming met land en volk - dreigt zulke streken tot vergetelheid te doemen, tenzij de ambtenaren bij het Binnenlandsch Bestuur, die door hun betrekking de aangewezen personen behooren te zijn om op het gebied van land- en volkenkunde voor te lichten, daarvoor waken door openbaarmaking van hetgeen hun op hun dienstreizen als vermeldenswaard voorkomt.

Alhoewel uit den aard der zaak het behandelde onderwerp slechts aan weinigen belang kan inboezemen, geeft deze overweging mij toch vrijheid een, zij 't dan ook nog ver van volledige, bijdrage tot de kennis van een nog weinig bekend gedeelte van Sumatra's Oostkust te leveren. 
't Was 9 uur en mistig weêr; een van die kille ochtenden, zooals er in de maand November zoo dikwerf op de Oostkust van Sumatra voorkomen en welke eerder herinneren aan een guren herfstdag in Holland dan aan een heerlijk tropisch klimaat. De gouvernements stoombarkas "Slamat" lag reeds langer dan één uur tot vertrek gereed, toen eindelijk, op het herhaald geroep van de stoomffuit, mijn beide inlandsche reisgezellen, twee Datoe's van Beneden Langkat, met hun prauwtje langs zij kwamen. Het anker werd spoedig gelicht en voortgestuwd door een vliegenden stroom het was bandjir in de rivier - bereikten wij reeds na éen uur stoomens de monding der Langkat-rivier. Alles hehalve aanlokkelijk zag het weêr er daarbuiten uit. Niet zoozeer de hooge golfslag, dan wel de zware deining, een gevolg van hevigen wind den vorigen dag, was oorzaak dat ons vaartuigje slingerde en stampte, zoo zelfs dat een oogenblik an terugkeer wegens te hooge zee moest worden gedacht. De inlandsche gezagvoerder (djoeragan) van het bootje stelde ons echter gerust; telkens wanneer wij de een of andere buiteling hadden gemaakt, gaf ons zijn "tida apa " ${ }^{1}$ weêr nieuwen moed, hetgeen evenwel niet wegnam, dat wij ons niet zeer op ons gemak voelden en blijde waren dat de regenvlagen ophielden en de zee wat kalmer werd.

Langs de kust stoomende, zoodra wij bij de buitenbaak van de geul der Langkat-rivier dieper water kregen, konden wij thans de Serapoh- en Gebang-rivieren, beide vrij diep, doch weinig landinwaarts stroomende, onderscheiden en ruim een half uur later kregen wij de mondingen van de Lepan- en Babalan-rivieren in 't gezicht.

De Lepan-rivier, ofschoon door de zandbank, welke zich voor de monding gevormd heeft, voor eenigszins diepgaande scheepjes moeilijk binnen te komen, is op zich zelf diep genoeg om door een stoomer van \pm 6 voet diepgang gedurende 3 uren te worden opgestoomd tot aan de kampong Alor Item en hooger op voor tamelijk groote prauwen nog een heel eind bevaarbaar. De Babalan-rivier is eigenlijk meer een zee-arm, welke gemakkelijk voor 7 à 8 voet diepgaande schepen bij laag water is binnen te varen, doch hoogerop voor scheepvaart van geen belang.

1 't Is niets. 
Niet ver voorbij de monding der Babalan-rivier passeerden wij den zuidelijken ingang tot de Aroe-baai, een vrij diep vaarwater tusschen den Sumatra-wal en Poelau Sembilan dat echter evenals nagenoeg alle rivieren op dit gedeelte van Sumatra's Oostkust, vanwege een daarvoor gelegen bank voor grootere schepen moeilijk is binnen to komen Den noordelijken ingang tot de baai bereikten wij na ongeveer $4 \frac{1}{2}$ uur stoomens van Tandjong Poera; de geul is behoorlijk afgebakend; en daar hier bij laag water nog altijd 8 ì 10 voet water staat, hadden wij minder last van de deining dan bij het uitstoomen van de Langkat-rivier. Tusschen de eilanden Kampei en Sembilan stoomden wị in minder onstuimig vaarwater de Aroebaai binnen.

Poelau Kampei levert uit zee gezien een aangenamen aanblik op; het helderwitte strand gaat langzaam over tot hooger terrein met lichtgroen gras, waarachter in de verte de versterkte huizen van Datoe Bintara en den inlandschen opziener der rechten te voorschijn komen; het geheel maakt den indruk alsof men een fort met borstwering voor zich ziet. Als men evenwel den hoek van Poelau Kampei omstoomt, maakt die indruk weldra plaats voor een geheel anderen en ontwaart men dat de eigenlijke kampong uit eenige vervallen atap-huisjes bestaat. waarvan er sommigen op palen aan 't strand zijn gebouwd. ${ }^{1} \mathrm{Na}$ drie kwartier varen langs bakens, welke ook in de baai de geul angeven, kwamen wij te Pangkalan-Siata, gelegen aan de monding der Salahhadji-rivier.

De overtocht had dus in 't geheel ruim $5 \frac{1}{2}$ uur geduurd, juist lang genoeg om te beseffen dat in dezen tijd van het jaar het varen met kleine, niet zeer zeewaardige stoomertjes in de straat van Malakka met zijn plotselinge hevige windvlagen - de zeelieden noemen die "de Sumatraan" - niet alles is.

Het is eigenaardig dat, zoodra men na een vrij onaangename zee-

1 Poelau Kampei gaat in den laatsten tijd meer en meer vooruit, doordat zieh daar vele Chineezen neerzetten, wier aantal thans reeds tot ruim 300 geklommen is. De vorm van het eiland is ongeveer die van een halven cirkel, warvan de middellijn, welke eene noord-zuidelijke riehting heeft en die de oost(zee) zijde vormt, een lengte heeft van $t 9$ kilometer. Men mag aannemen dat dit eiland niet door aanslibbing is ontstaan, aangezien het door een vrij diepe straat van den rasten wal en het naburige Poelau Sembilan is gescheiden, terwijl de formatie van het eiland evenzeer van ouder dagteekening is dan die van den vasten wal. Heuvels die misschien $150^{\prime}$ i $500^{\prime}$ boven de zee zich verheffen, door even diepe dalen geseheiden of door plateau's verbonden, bedekken het eiland en makt de strand-vegetatie al zeer spoedig voor landvegetatie plate. 
reis, weder vasten grond onder de voeten heeft, de herinneringen aan de uitgestane ellende langzamerhand verflauwt en zoo ging het ook ons; vooral onder den indruk van de gastvrije ontvangst van den administrateur der op Pangkalan-Siata gevestigde houtaankap, begonnen wij ons zeetochtje al spoedig als een pleizierreisje te beschouwen. $\mathrm{Na}$ ons een weinig verfrischt te hebben, namen wij het plaatsje meer in oogenschouw en verwonderden ons niet weinig over de zeldzame bedrijvigheid welke er heerschte. In plaats van een armoedig houtzagerijtje met dito etablissement, troffen we hier een onderneming, op flinke schaal aangelegd, aan. Behalve de woningen voor administrateur en emploijés, waren de noodige koeliehuizen en verdere gebonwen voor het personeel aangebouwd; twee groote raamzagen waren den geheelen dag in beweging en twee cirkelzagen snorden onder een oorverdoovend geraas steeds door. In 1876 opgericht, had de Kali-anam-Maatschappij hier een ontzachlijk stuk grond tot hare beschikking; op verschillende plaatsen werden door javaansche koelies de bruikbare houtsoorten, waaronder in de eerste plaats het deugdzame Damar-hout gekapt en naar de zagerij gebracht om tot planken en balken te worden verwerkt. Beschikkende over een groot décauville-materieel kon door die Maatschappij uit diep binnenwaarts gelegen plaatsen het zware hout naar den rivieroever worden getransporteerd, om verder, aan lichtere houtsoorten gebonden, drijvende naar Pangkalan-Siata te worden overgevoerd.

Het schijnt dat deze onderneming in den beginne niet met voldoende kennis van zaken op touw is gezet; anders is het niet te begrijpen dat zij wegens aanhoudende verliezen heeft moeten sluiten. Een houtaankap in deze, aan kostbare houtsoorten zoo rijke"streek, heeft toch alleszius reden van bestaan. Wel is waar zijn met de exploitatie van zulk een houtaankap groote kapitalen gemoeid, doordat het overbrengen van het gekapte hout naar de zagerij zeer kostbaar wordt, doch de waarde van het hout en de vraag daarnaar zijn van dien aard dat, mogen er al geen groote winsten worden behaald, er ook geen verliezen behoeven te worden geledeu. Voor het naburige Deli, waar reeds gebrek aan goede houtsoorten begint te heerschen, was de houtaankap te Pangkalan-Siata van veel waarde en blijft het dan ook zeer te betreuren dat de Kali-anam Maatschappij hare zaken aan kant moest doen, waardoor bovendien nog het vertrouwen in dergelijke nuttige ondernemingen werd geschokt en een groote steun voor de ontwikkeling van de omstreken van de Aroe-baai werd ontnomen, 
Wie thans Pangkalan-Siata bezoekt, treft daar niets meer aan van de vroegere levendigheid.

Een door houten palissaden omgeven kampement, waarvan de verdediging is opgedragen aan een Officier en 30 soldaten, is het eenige wat nog van de vestiging te Pangkalan-Siata is overgebleven, behalve nog een tiental vervallen atappen-woningen van lieden, die zich met het kappen van hout en vischvangst bezig houden. Weldra zullen ook die laatste overblijfselen verdwijnen, aangezien in 't begin van 1888 de benting zal worden overgebracht naar Tandjong Koeboe, aan de Besitang-rivier gelegen, en dan nog slechts een uit het bosch opengekapte plek de plaats aanwijzen, waar eenmaal de houtaankap der Kali-anam-Maatschappij was. Doch moge deze plek weder tot haar vroegeren staat van wildernis terugkeeren, toch zal een bezoek daaraan steeds beloond worden door een prachtig vergezicht, dat men van de heuvels heeft op de Aroe-baai, welke van hier in haar gansche uitgestrektheid is waar te nemen. Een blik op die watermassa, omgeven door een lijst van rizophoren, welke door hun afwisselend groen de noodige kleurschakeeringen aanbrengen, geelt zulk een indruk van kalmte en vreedzaamheid, dat men zich moeilijk kan voorstellen, dat hier in de $16^{\mathbf{e}}$ eeuw de zetel moet zijn geweest van een rijk, dat in grootheid en macht met het toenmalige Pasei en Malakka. kon wedijveren. Niets dat ons hier herinnert aan het eertijds zoo machtige rijk Aroe, dan de naam van de baai, welke ons nog boeit en welke onder de inlanders bekend staat onder den naam van Telok Aroe.

Men zou bijna geneigd zijn om na kennismaking met die eenzame streek, welke haar oorspronkelijke bevolking eens moet verloren hebben en eerst sedert een 100tal jaren opnieuw door vreemde elementen werd bevolkt, de meening op te geven dat hier eens de zetel moet zijn geweest van het rijk Aroe, ware het niet dat eenige aanwijzingen zoowel als geschiedkundige overleveringen ons niet meer aan het vroeger bestaan van dat Rijk op dit gedeelte van Sumatra's Oostkust mogen doen twijfelen. Een zoodanige aanwijzing vinden wij bijv. in het aanwezig zijn van een soekoe Aroe onder de tegenwoordige bevolking van de tot Siak behoorende landschappen Koeboe en Bangka, waarvan de leden, bịj onderzoek naar de streek waar zij thuis behooren, verklaren dat zij uit de omstreken van de Aroebaai afkomstig zịjn ${ }^{1}$. Ook in $\Lambda$ tjeh en onder de Gaijoes treft men

1 Zie hierover mijne "Beschrijving eener reis van Bengkalis langs de Rokanrivier naar Rantau Binoewang in dit Tijdschrift, 4e volgreeks VIII, bl. 8 (overdruk). 
een soekoe Aroe aan en het lijdt geen twijfel, of ook daar ontleent die soekoe haar naam aan het vroegere rijk van dien naam. Een andere aanwijzing vinden wij in een tweetal overblijfselen van versterkingen een weinig het binnenland in aan de soengei's Si-Koendoer en Serang djaja gelegen, welke ons gezegd worden oude bentengs van de vroegere vorsten van het rijk Aroe te zijn geweest. Evenzoo wijst de overlevering op Poelau Mesigit de plaats aan, waar de moskee van Aroe heeft gestaan en zoude de naam van de in de Besitang-rivier uitloopende Soengei Si-Djanda nog betrekking hebben op de weduwe ${ }^{1}$ van den laatsten vorst van Aroe, die bij de verwoesting van het rijk door Atjeh naar genoemde Soengei vluchtte.

Wat overigens de overlevering aangaat, daaruit kunnen wij slechts weinig bizonderheden putten; zij verhaalt ons enkel dat aan de Aroe-baai de hoofdzetel van het rijk Aroe is geweest en verder dat dit rijk zich langs een groot gedeelte van Sumatra's Oostkust heeft uitgestrekt. Wijders dat het was een Batak-rijk, dat na langdurigen strijd door Atjeh ten gevolge van gepleegd verraad werd ten onder gebracht, ${ }^{2}$ waarna de bevolking zich in de binnenlanden terugtrok of elders zich verspreidde.

Het zou natuurlijk niet aangaan om uit bovenvermelde aanwijzingen en overleveringen al aanstonds te besluiten, dat in de omstreken van de Aroe-baai de hoofdzetel van het rijk van dien naam moet zijn geweest, te meer daar geschiedverhalen van dien tijd het tegenwoordige Panei-gebied als zetel van dat rijk wordt genoemd. Maar toch mogen wij de waarde van die overlevering en het gewicht der aanwijzingen niet geheel wegcijferen, daar zij ons in staat stellen om het in de geschiedenis van dien tijd beschrevene aan te vullen en ons een betere voorstelling van zaken te geven.

Meer dan eene vage voorstelling van den loop der gebeurtenissen is evenwel niet mogelijk, waar ons bepaalde en vertrouwbare gegevens ontbreken en wij ons moeten behelpen met verhalen, welke, verward als zij zijn, ons slechts weinig op den rechten weg helpen. De voormaamste bronnen, waaruit wij een en ander omtrent het rijk Aroe kunnen te weten komen, vormen de geschiedverhalen van Portugeesche schrijvers uit dien tijd en in de eerste plaats van Mendez Pinto, wiens overigens zeer verdienstelijke beschrijvingen een

1 Djanda Gidau genaamd.

2 De overlevering, dat Atjeh zich door verraad van het land meester maakte, vindt men ook met betrekking tot andere rijkjes vermeld. Zie o. a. het rijk "Gassip" in het Tijdschrift van het Aardrijkskundig genootschap, tweede serie, dl. II $\mathbf{n}^{0} .2$, 
gebrek aan topografische kennis verraden, welke het ons bizonder moeilijk, ja dikwerf zelfs onmogelijk maakt om ons behoorlijk te kunnen orienteeren.

Zooveel is echter zeker dat wij in de $16 \mathrm{e}$ eeuw het bestaan van een rijk Aroe mogen aannemen, en dat dit rijk als een evenknie van Pasei (Atjeh) en Malakka moet worden beschouwd. Voorts is de onderstelling niet gewaagd dat de grenzen van het rijk zich in het noorden tot Atjeh en in het zuiden tot de Djohorsche nederzettingen aan de Rokan-rivier hebben uitgestrekt.

Waar de hoofdzetel van het rijk is geweest, laten wij hier in ' $t$ midden; en op de vraag tot welk ras de bevolking van Aroe behoorde, geeft de overlevering ons het antwoord. Algemeen toch wordt aangenomen, dat die bevolking tot het Batak-ras heeft behoord ', waarvan bij de Gaijoes nog duidelijk de overblijfselen worden aangetroffen.

Wij zullen, wat de geschiedenis betreft, de Portugeesche schrijvers niet volgen en belangstellenden verwijzen naar hetgeen Tiele daaromtrent mededeelt in zijn werk: "De Europeeërs in den Maleischen Archipel. " 2 Slechts teekenen wij hier nog aan, dat zoowel de geschiedenis als de overlevering den voortdurenden en hardnekkigen strijd tusschen Aroe en Atjeh in een helder licht stelt, welke strijd eindigt met de algeheele vernietiging van Aroe in de tweede helft der zestiende eeuw, waarbij dit rijk een onderhoorigheid van Atjeh wordt. $\mathrm{Na}$ dien tijd vinden wij niets meer omtrent het rijk Aroe vermeld, zoodat wij veilig mogen aannemen, dat de bevolking zich terugtrok naar de binnenlanden of elders een goed heenkomen zocht om het Atjehsche juk te ontgaan. Ook de Atjehers schijnen het hier niet lang te hebben gemaakt; ten minste de overlevering gewaagt er van dat de Atjehsche prins later naar zijn land terugkeerde en de omstreken van de Aroe-baai onbewoond achterliet tot groot gerief van een aantal zeeroovers, die in deze door talrijke kleine riviertjes besproeide streek steeds een veilige schuilplaats vonden. Die onveiligheid was zeker oorzaak dat niemamd het durfde wagen zich aan de Aroe-baai te vestigen; het moet daar dan ook een waar zeerooversnest zijn geweest, waaruit herhaaldelijk strooptochten werden georganiseerd. Het optreden van het Nederlandsch Gouvernement op de Oostkust van Sumatra maakte hieraan een einde eu

1 Zie Neumann, "Het Pané en Bila stroomgebied" in het Tijdschrift van het Aardrijkskundig genootschap, 2e afdeeling, 2e serie, Deel III.

2 Tweede gedeclte: 7e hoofdstuk. Vierde gedeelte: 4e hoofdstuk. 
er deden zich geen belangrijke gevallen van zeerooverij meer voor sedert $\mathrm{Zr}$. Ms, oorlogschepen zich in deze wateren hebben vertoond.

II.

Den dag na onze aankomst te Pangkalan-Siata vertrokken wịj des morgens om 7 uur met de steamlaunch en stoomden langs den vasten wal, het eilandje Talang links latende liggen. Wij passeerden hier Oedjoeng Batoe, waar een afdeeling van de houtaankap door een weg met Pangkalan-Siata verbonden was, en staken van de iets verder gelegen Soengei Brasbasa over naar Pangkalan Soesoe, waar een 10tal woningen van uit Besitang gevluchte maleiers op den hoogen oever waren gebouwd. ${ }^{1}$ Behalve de bewoners, die zich met vischvangst bezighouden, wonen hier een 30 -tal chineezen, die hier op de ruwste manier het deugdzame damar-hout wegkappen. De boomen, waaronder pracht- exemplaren, worden geveld en in het bosch gezaagd tot balken en planken, waarbij veel hout verloren gaat, aangezien het niet der moeite waard wordt geacht om de stukken, welke te diep in de ravijnen vallen, te gebruiken. De damar-boomen staan, eenigen bij elkauder, op de heuvels, welke in deze lage streken zich dikwerf tot 150 à 200 voet verheffen en de houtkappers verhuizen telkens, wanneer het hout op zulk een heuvel is weggekapt. De balken worden dan door karbouwen naar den rivier-oever gesleept.

In Pangkalan Soesoe moet in vroeger jaren een groote kampong zijn geweest, welke door zeeroovers is verwoest. Op het hierover gelegen eilandje Mesigit, dat met den wal eertijds verbonden was, had, gelijk wij boven reeds aanteekenden, volgens de overlevering, de moskee gestaan, doch te vergeefs zoekt men hier naar eenig overblijfsel, dat de juistheid der beweringen van de Maleiers kan staven. De tegenover Pangkalan Soesoe gelegen eilandjes loopen bij hoog water grootendeels onder water, terwijl bij laag water tusschen die eilandjes modderbanken te voorschijn komen, die elk jaar duidelijker zichtbaar worden. Het is dan ook te voorzien, dat het tusschen die eilandjes zoo aanslibt, dat er na niet langen tijd één groot eiland zal zijn gevormd.

Het tegenover Pangkalan Soesoe gelegen eiland Sembilan bestaat uit een aaneenschakeling van grootere en kleinere heuvels. Volgens

1 Uit Besitang gevlucht tijdens den inval van Atjehsche benden in Langkat in 't begin van 1886. 
de overlevering is dit eiland hierheen gekomen van den overwal en zou het behoord hebben tot de negen eilanden bij Koenala Pérak, waar nu nog 8 eilanden moeten liggen. Dezelfde overlevering verhaalt ons dat dit eiland zou huwen met Poelau Salahadji, doch niet verder kon komen dan de tegeuwoordige plaats, waar het ten anker ging voor een boom, welke nu nog wordt aangetrofien en die bij hoog zoowel als bij laag water in de Aroe-baai zichtbaar is en altijd even ver boven water uitsteekt. De inlanders in deze streken gaan dikwerf offeren aan dien boom en hebben ook veel eerbied voor Poelau Sembilan, waar geen hunner een boom zal kappen.

Van Pangkalan Soesoe stoomden wij terug langs Tandjong Roebia, een afdeeling van de houtaankap en langs Tandjong Panei, de Besitang-rivier in. Tandjong-Panei is een vooruitspringende hoek met twee steile heuvels aan den voet, waarvan een kampong met een 40 tal huizen, bewoond door Maleiers van P. Pinang, die hier ataps maken. Dergelijke kampongs, waarvan de geheele bevolking bestaat uit atapcontractanten, vindt men nog, de Besitang-rivier op, te TamboenToelang en te Meran. De atapwerkers ontvangen van den een of anderen anak-radja voorschotten en leveren daarvoor ataps tegen 9 dollar de 1000 stuks; hun verdiensten kunnen hoogstens drie dollar per dag bedragen, daar 300 ataps het grootste aantal is, dat éen man per dag kan afwerken.

De Besitang-rivier is aan de monding zeer breed; voor de monding ligt een zandbank over de geheele rivier-breedte, waaraan de landstreek, volgens de overlevering, haar naam ontleent ' ${ }^{1}$. Daar bij laag water op deze bank slechts 3 voet water staat, moet men met hoog water binnen komen. Overigens is de rivier voldoende diep en belemmert slechts hier en daar een boomstam de vaart. Bij Tamhoen Toelang wordt de rivier minder breed en allengs smaller, zoodat die boven de kampong Besitang, ongeveer een half uur stoomen van de monding, nog slechts voor prauwen bevaarbaar is.

De kampong Besitang bestaat uit een twintigtal woningen, welke er vervallen uitzien; het eenige huis, dat nog eenig aanzien heeft, is dat van den Datoe van Besitang, gelijk het hoofd van deze streek getiteld is. Al aanstonds merkt men op dat hier weinig welvaart heerscht; juist eenigen tijd voor ons bezoek had een gedeelte van het volk de kampong verlaten ten gevolge van een bezoek van

\footnotetext{
${ }^{1}$ Besitaing van Besi melintang. De bank wordt hier beschouwd als een ijzer dat dwars over de rivier ligt.
} 
Atjehers, die in de kampong een nachtverblijf hadden gevonden. Ook hier houdt de bevolking zich bezig met het maken van atap, waarvoor de overvloedig in alle riviertjes en kreekjes voorkomende nipah het gewenschte materiaal levert, terwijl de nabij gelegen onmetelijke bosschen de gewone boschproducten als rottan en getah gemakkelijk doen verkrijgen.

Door eene palisadering van wildhout omgeven, is de kampong in tegenweer voor hernieuwde aanvallen van Atjehers gebracht. Communicatie bestaat van hier, behalve langs de rivier, over land naar de Lepan-rivier en naar de Halahan en Tongkam-rivieren. Deze wegen zijn echter slechts voctpaden, welke weinig worden begaan en door meestal vrij geaccidenteerd terrein.

Van Besitang keerden wij weder naar Pangkalan-Siata denzelfden dag terug, na even te zijn aangegaan op het even beneden de kampong gelegen Boekit Koeboe, waar thans de nieuwe benteng ter vervanging van die te Pangkalan Siata wordt gebouwd. Deze Boekit ligt aan den rivieroever en is een van die verheffingen van den bodem, zooals die zoo menigvuldig in deze streken worden aangetroffen.

Op den terugtocht hadden wij gelegenheid een en ander te vernemen omtrent de latere geschiedenis van het tegenwoordige Besitang en het ontstaan van deze onderhoorigheid van Langkat. Daar deze geschiedenis ten deele samenvalt met de vestiging van Atjehers op Poelau Kampei, zullen wij die gezamenlijk behandelen tot op den tijd dat de vader van den tegenwoordigen Datoe het bestuur over Besitang aanvaardde.

Ongeveer 100 jaren geleden trok een Atjeher, Brahim genaamd, naar Deli en van daar naar Langkat, waar hij zich in Selesei 1 in de kampong Sakoeda vestigde. Hij hield zich daar voornamelijk met landbouw bezig en plantte eenige o. a. doerian-boomen welke thans nog daar worden aangewezen. Brahim trad daar, als het noodig was, ook als voorvechter op, waarbij hij zich steeds dapper betoonde en zich den bijnaam van Panglima Djafar ${ }^{2}$ verwierf. Hij had drie zoons, waarvan de oudste Hassan, de tweede Moedjoet en de jongste Ma'alim heette. Hassan had twee kinderen, Moedjoet twee dochters, Timpa en Kidoe genaamd en Ma'alim vier zoons, nl. Panglima Sidjat, Sinoe, Awal en Saleh, benevens twee dochters.

De toenmalige vorst van Tamiang, een onderhoorigheid van Atjeh

1 Gelegen in Boven-Langkat, onder een Kedjoeroean.

${ }^{2}$ Volgens de overlevering gaf hij zich zelf dien titel, hetgeen wel meer gebeurde bij lieden, die wegens hun dapperheid bekend stonden. 
in dien tijd, was Tongkoe moeda Tjoet Bagam, die van daar over Poelau Kampei naar Langkat reisde om zich een vrouw te zoeken. Zijn oog viel daar op Kidoe, de dochter van Moedjoet, die hij dan ook huwde, terwijl hij Besitang aan Moedjoet als huwelijksgift wegschonk. Hieruit blijkt, dat de vorst van Tamiang anspraak maakte op de omstreken van de Aroebaai.

$\mathrm{Na}$ den dood van Moedjoet, die zich aan de Besitang-rivier had gevestigd, ter plaatse waar thans nog de kampong van dien naam is, werd hij opgevolgd door zijn jongeren broer Ma'alim. Diens zoon, Panglima Sidjat, aan wien vele avonturen worden toegeschreven, deed een uitstapje naar Soengei Boeloe, bij de koewala Belawan (Deli) gelegen en zeilde van daar met zekeren Nakoda Kadir naar Poelau Pinang van waar hij naar Soengei Moenang, eveneens een zijtakje van de Belawan-rivier, terugkeerde.

Daar aangekomen, kreeg hij met Nakoda Kadir twist en schijnt hij zich van diens prauw te hebben meesier gemaakt; ten minste hij is met dat vaartuig naar Tamiang gegaan, waar hij het aan Tongkoe moeda Tjoet Bagam ten geschenke aanbood. De vorst van Tamiang was daarmede zeer ingenomen en schonk aan Panglima Sidjat Besitang weg of liever bevestigde hem in het bezit van die landstreek, waar inmiddels Ma'alim was overleden ${ }^{1}$.

Panglima Sidjat bleef in kampong Besitang wonen en overleed daar. Hij werd opgevolgd door zijn jongeren broeder Awal, meer bekend onder den naam Mandja Kaija.

Laatstgenoemde werd door den Pangéran van Langkat, den tegenwoordigen Sultan, te hulp geroepen in een strijd dien deze met den Kedjoeroean van Selesei, een der hoofden van Boven-Langkat, voerde. Aanvankelijk weigerde Mandja Kaija naar Langkat te gaan, doch na drie malen te zijn gevraagd, vertrok hij eindelijk met eenige volgelingen en een zekeren Panglima moeda Ismail, een zoon van den bovengenoemden Hassan. In den strijd verloor Panglima moeda Ismail al spoedig het leven; hij werd door een van de hoofden van Si-abatabat, Imam Balé genaamd, gedood. Mandja Kaija liet echter zijn dood niet ongewroken; hij overviel Imam Balé in zijne woning, vermoordde hem en maakte zich meester van alles wat in huis was. Door het moedig gedrag van Mandja Kaija bleef de Pangéran overwinnaar in den strijd en ontving Mandja Kaija van dezen den gelar van

\footnotetext{
1 Panglima Sidjat kreeg dus Besitang krachtens een dubbel gunstbewijs van den Radja van Tamiang. 
Datoe Sri Maharadja Indra, terwijl de Pangéran hem als broeder aannam. Tevens schonk de Pangéran aan Mandja Kaija Besitang weg, erfelijk in zijn geslacht. Hieruit blijkt weder dat ook de Pangéran van Langkat aanspraak maakte op Besitang en moeten wij deze streek in dien tijd beschouwen als een terrein, dat nu eens door den vorst van Tamiang, dan weder door den vorst van Langkat als een onderhoorigheid werd gereclameerd, totdat Langkat, als overwinnaar in den strijd met Tamiang, een onbetwistbaar recht op Besitang kon doen gelden.

In dien strijd, welke kort na de boven beschreven gebeurtenissen plaats vond, kwam Mandja Kaija in een zeer lastige positie. Aan den eenen kant en wel in de eerste plaats was hij verplicht den vorst van Tamiang te helpen, maar aan den anderen kant kon hij toch weer moeielijk optreden tegen den Pangéran van Langkat, die hem zoo zeer genegen was en die hem als zijn broeder had aangenomen. Mandja Kaija koos de wijsste partij en bleef stil te Besitang den loop der gebeurtenissen afwachten. Zijn zoon Si Liija zond hij echter naar Tamiang om daar te helpen en deze weerde zieh dapper en tot groote tevredenheid van den vorst van Tamiang, die hem de gelar van Datoe Laksamana gaf. Tamiang mocht evenwel aan Langkat geen duurzamen weerstand bieden. Radja Bandahara, die daar aan den linker rivieroever het gezag in handen had, werd gevangen genomen en naar Langkat gevoerd, terwijl Soetan Seman, die aan den rechteroever van de Tamiang-rivier het bestuur voerde, de wijk nam naar Besitang. Nadat de Langkatsche troepen terug waren gekeerd, ging ook Soetan Seman weer naar zijn woonplaats en werd Tamiang een onderhoorigheid van langkat.

Zooals wel kan worden nagegaan, was de Pangéran van Langkat alles behalve ingenomen met de hulp, welke Mandja Kaija door 't zenden van zijn zoon Si Liija aan Tamiang had geboden. Si Liija moest dit ondervinden, toen hij, naar langkat opgeroepen om tegenwoordig te zijn bij het besnijdenisfeest van's Pangérans zoon Tongkoe Oemar, daar eenvoudig werd aangehouden, totdat hij op zekeren dag in het water springende zich uit de voeten maakte en naar Besitang terugkeerde. Aldaar volgde hij kort daarna zijn vader Mandja Kaija op, die, zooals wij straks zullen zien, ten gevolge van een in Tamiang gekregen wond overleed. Onder den gelar van Datoe Laksamana trad hij als hoofd in Besitang op en stelde zich tegenover den Pangéran op een vrij onafhankelijk standpunt. Dit nam echter niet weg, dat de Pangéran zijne hulp inriep in een strijd met 
den Soetan van Si-Abat-abat. Tot zes malen weigerde Datoe Lakkamana om te komen, uit vrees voor rancune van den lant van den Pangeran, doch sindelijk ging hij en hielp den Pangeran met zooved toewijding en dapperheid, dat de lieden van Si-Abat-abat werden geslagen en zich moesten onderwerpen. Tot belooning ontving hij de gelar van Datoe Djohan Pahlawan ens schonk de Pangéran hen een acte van asustelling, waarin bijne rechten cn nerpliehtingen waren vermeld i. De bovenstaande gebeurteniegen viden voor, lorten tijd voordat het Nederlandsch-Indische Gonvernement in deze streken zinn invloed deel gelden (1837).

Wij zullea hier de gresehiedenis van Besitang vordoopig af brekesi en eens nagaan wat er voorviel on Poelau Tamper, het éland aan den ingang van de Aroe-basi, anan de nitmonding der Serangdjajjariwier gelegen. Ten tijde van Modjoet (zie boven) vestigde zich op

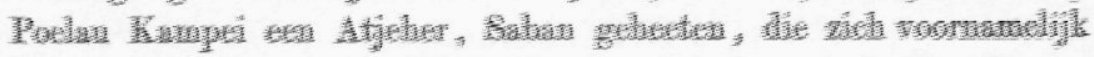
met vischwangst onledig hield. Toen un Thougke noeld Toet Tagam van zijn tocht nas langkat, waar hij, selijk wij zaseen, Tidoe had gehuwd, over Poelau Kampei terugkeerde, schonk hij aan Saban den titel van Kedjoeroean Poelau Kampei. Van zijne zes kinderen, vier zoons en twee dochters, volgde Njaq Assan zijn vader op en was deze op Poelau Kampei, toen Tongkoe Hassim zich daar vestigde. Deze Tongkoe Hassim was een Atjehsch avonturier, die zich met behulp van de Tamiangsche bevolking op Poelau Kampei een benteng bouwde en zich geheel en al als heer in deze streken gedroeg. Hij beweerde zijn gezag aan den Sultan van Atjeh te ontleenen en matigde zich veel aan. Zoo ontbood hij Mandja Kaija naar Poelau Kampei om zich door dezen hulde te doen bewijzen en door hem te worden erkend, doch MandjaKaija weigerde eenvoudig om aan die oproeping gehoor te geven.

Korten tijd hierna begaf Tongkoe Hassim zich naar Langkat en liet hij als gemachtigde op Poelau Kampei achter zekeren Toekoe Tepin, een Merdoeër, die de dochter van Mandja Kaija ten huwelijk vroeg. Mandja Kaija weigerde en Toekoe Tepin vertrok zeer vertoornd naar Langkat om Tongkoe Hassim en den Pangéran te vragen, hem vergunning te geven Mandja Kaija te bevechten en Besitang ten onder te brengen. Aanvankelijk wilde de Pangéran geen toestemming geven, doch Toekoe Tepin hield aan en schoot zelfs een geweer af tegen zijn (eigen) borst, zonder zich te verwonden, waar-

1 Deze acte is gedateerd 14 Djoemadilachir 1272 (1855 ong.). 
door hij een bewijs voor zijn onkwetsbaarheid wilde leveren, zoodat eindelijk de Pangéran toegaf en Tepin naar Besitang vertrok. Ter plaatse, waar thans Tandjong Koeboe is, werd Toekoe Tepin opgewacht door Mandja Kaija's zoon Si Liija, die een gevecht begon, hetwelk eindigde met den dood van Tepin, die door Si Liija werd doorstoken.

Intusschen bleef Tongkoe Hassim in Langkat, waar hij de dochṭer van den Pangéran, Tongkoe Oebong, de zuster van Tongkoe Hamza ${ }^{1}$, hnwde. Weldra wist hij grooten invloed te verkrijgen, zoo zelfs, dat de Pangéran hem als gemachtigde (wakil) achterliet, toen hij naar Tamiang ging, om dat landschap te onderwerpen. Van de afwezigheid van den Pangéran maakte Tongkoe Hassim gebruik om zijn invloed te versterken en uit te breiden en zette hij de bovenlandsche Radja's, voornamelijk die van Si-Abat-abat tegen den Pangéran op. De zoons van den Pangéran noodzaakte hij het land te verlaten, in één woord, hij wist zich zooveel gezag aan te matigen, dat de Pangéran, aan de monding der Langkat-rivier van den toestand verwittigd, het onraadzaam achtte naar Langkat terug te keeren na zijn tocht in Tamiang. De Pangéran toog naar Batoe Bara, waarheen ook zijne zoons waren uitgeweken, en overlegde daar om naar Riouw te gaan en de hulp van het Nederlandsch-Indische Gouvernement tot verdrijving van Tongkoe Hassim in te roepen. De toenmalige Resident van Riouw verleende die hulp en zond naar Langkat een oorlogsschip, dat echter Tongkoe Hassim niet meer aantrof, daar deze de wijk naar Poelau Kampei had genomen. Doch ook van Poelau Kampei werd hij verjaagd en gedwongen naar Tamiang te vluchten, waar hij zich voorloopig ophield.

Ofschoon nu daartoe geen reden bestond, werd de bovenbedoelde Njaq Assan, die nog steeds op Poelau Kamrei was, door het oorlogsschip naar Batavia gebracht, vanwaar hij echter spoedig terugkeerde, nadat zijn onschuld was gebleken. Teruggekomen deed hij het voorkomen alsof het Nederlandsch-Indische Gouvernement hem Poelau Kampei had geschonken, totdat hij eensklaps was verdwenen en men niets meer van hem vernam dan dat hij naar Langsar was gegaan. Hij werd opgevolgd door den zoon van zijn broeder Njaq Item, die, bekend onder den naam van Panglima Prang, Poelau Kampei verliet en naar Tandjong Semantok ging, waar hij nu nog verblijf houdt bij den Radja Toekoe moeda Latip.

1 Thans hoofd van den Karapatan (rijksraad) van Beneden-Langkat. 
Zooals wij zagen, trok Tongkoe Hassim naar Tamiang; hij was nog altijd zeer vertoornd over den moord op Toekoe Tepin en wilde dezen niet ongewroken laten. Hij bewoog Mandja Kaija naar Tamiang te komen en ontving hem voor 't oog zeer vriendschappelijk. Toen Mandja Kaija des avonds naar zijn prauw wilde terugkeeren, liet Tongkoe Hassim hem bijlichten; de trap afgaande werd hij overvallen door lieden met donderbussen gewapend, bij welke gelegenheid twee volgelingen van Mandja Kaija werden vermoord en hem zelf een knie verbrijzeld. Hij wist evenwel nog te ontkomen; bereikte zwemmende den wal en ging naar Besitang, waar hij nog eenigen tijd leefde en later aan de gevolgen van zijne wonden overleed. Tongkoe Hassim vertrok van Tamiang naar Langsar, om niet meer in deze streken terug te keeren en moet hij thans in Kemala verblijf houden.

\section{III.}

De Salahhadji-rivier is voor een stoombarkas slechts tot Boekit Kramat op te stoomen, niet zoozeer doordat de rivier daar te ondiep wordt, doch door de vele boomstammen, welke hier het vaarwater onveilig maken. $\mathrm{Na}$ drie kwartier stoomens bereikten we laatstgenoemde plaats, na een 3-tal kleine Soengei's, bekend onder den naam van Soengei Satoe, S. doewa en S. tiga te zijn gepasseerd. Geen van die riviertjes is voor prauwen van eenige grootte ver van de monding bevaarbaar en ze dienen dan ook alleen voor den inlander tot weg om van daar uit naar de onmetelijke bosschen te gaan voor de inzameling van bijenwas en andere boschproducten. Van de Soengei Satoe loopt een voetpad naar Soengkam (waarover later) dat echter zeer moeilijk is te begaan.

Te Boekit Kramat, zooals de naam reeds aanduidt, een grafheuvel, troflen wij de overblijfselen aan van een wachtpost, welke daar vroeger door een sergeant en eenige minderen van uit Koewala Simpang, aan de samenvloeiing der Simpang Kiri en Kanan werd bezet. Deze post werd in 18(?) door Atjehers afgeloopen, waarbij eenige militairen werden vermoord, waaaronder ook de commandant, wiens graf thans nog door een kruis in deze wildernis wordt aangewezen. Van Boekit Kramat vervolgden wij onzen tocht over land naar Salahhadji langs een zeer verwaarloosden weg door verlaten pepertuinen, ladangs en tabaksvelden. In de Kampong zelve, twee en een half uur gaans van Boekit Kramat, waren nog slechts weinige huizen over, die ongeveer 20 in getal zeer vervallen en wijd uit elkander waren gebouwd. 
Een tamelijk hechte, van planken gebouwde woning behoorde den Datoe van Besitang toe en hier rustten wij een poosje nit van onzen vrij vermoeienden wandeltochṭ.

Het is hier de plaats een oogenblik stil te staan bij de gebeurtenissen, welke in den laatsten tijd in Salahhadji hadden plaats gevonden en die ten deele tot algeheelen achteruitgang van deze streek hebben geleid.

Zooals wij boven zagen, schonk de Pangéran van Langkat aan Si Liija als belooning voor zijne hulp tegen Si-Abat den titel van Datoe Djohan Pahlawan. Deze keerde daarop naar Besitang terug en bouwde zich een huis in Salahhadji, waar hij pepertuinen aanlegde. De pepercultuur had toen reeds in die streek een niet onbelangrijke uitbreiding ondergaan, onder de peperhoofden Lebei Oesoes (afkomstig uit Samalangan) Prada en Katib Tjigoel (beiden Tamiangers) en Panglima moeda Semin, een Pedirees. Laatstgenoemde werd door Datoe Djohan als kind aangenomen, waardoor hij zijn invloed in het eigenlijk onder het gebied van Kedjoeroean moeda (Tamiang) ressorteerende landschap Salahhadji, aanmerkelijk versterkte.

Intusschen had ook de europeesche landbonwindustrie haar oog op deze streken laten vallen en werden door den Pangéran een aantal landbouwcontracten uitgegeven, waarvan er echter slechts één in exploitatie kwam. Ook deze onderneming, de Agnieta-plantage, werd later gesloten, ten gevolge van een reeks van gebeurtenissen, welke ook het geheele verloop van de pepercultuur in Salahhadji na zich sleepten.

Het eerste van die voorvallen is de aanval van Gaijoes op het huis van den heer Steck, administrateur der Agnieta-plantage, te Boekit Assem in het begin van 1877. Datoe Djohan was toen juist voor een zaak naar Langkat opgeroepen, van waar hij onmiddellijk naar Salahhadji terugkeerde. Zijn zoon Orang kaja Brahim, die tijdens den overval in Besitang was, vertrok ook naar Salahhadji, waar hij van den heer Steck geld en opium wist te verkrijgen ten einde de Gaijoes te kunnen opvatten. Orang kaja Brahim vertrok echter zonder iets uitterichten naar Tongkam en keerde van daar naar Besitang terug.

Aan de politie gelukte het de Gaijoes te achterhalen; zij werden nog in het bezit gevonden van eenige gestolen goederen en op de vlucht gejaagd, waarbij zij twee dooden achterlieten.

Korten tijd daarna had een tweede aanval op de Agnita-plantage en wel te Alor-poetih plaats door een 30-tal Atjehers, die onder 
aanvoering van zekeren Panglima Tjoet, van Telaga Mockoe gekomen waren. Zoowel Datoe Djohan als zijn zoon Orang kaja Brahim waren toen in Langkat, werwarts zij waren ontboden, ten einde zich te verantwoorden op een aanklacht van Kedjoeroean moeda betreffende de beslissing van Datoe Djohan in zake twee misdrijven, in = één waarvan Orang kaja Brahim betrokken was.

Datoe Djohan keerde ook nu direct naar Balahhaji terug, war hij vemam dat het voomemen van cen amval reeds eenigen tijd te voren bekend was geweest en dat toen Jebei Bantah, een Atjehsch atap-contractant en de zwager van Datoe Djohan om beurten de wacht te Alor-poetih hadden gohouden. Panglima Tjoet werd taruggeslagen en gedwongen naar de Serang djaja cn daama nar Tamiang terug te keeren.

Het is hier niet de plats on na te gaan wat de oorzak was, welke aanleiding gaf lot bovenvermelde gebentenisen, evenmin in hoeverre de van bestuurswege genomen matregelen tot, het gewensehte doel: n. 1. verzekering van de veiligheid in Gahahadj konden leiden. Genoeg zij het hier aan te teekenen dat Orang kaja Brahim werd gevangen genomen en dat een aantal arrestaties van verdachte personen, die later gedeeltelijk weêr werden vrijgelaten, plaats had, terwijl in Salahhadji een benteng werd opgericht, welke in 1879 naar Koewala Simpang werd verplaatst.

Datoe Djohan Pahlawan werd daarna naar Langkat ontboden, doch hij weigerde op te komen, begaf zich naar Koewala Simpang en verder naar Kaloewi, aan de Simpang-kiri gelegen. Van daar ging hij naar de boven-Besitang en zond hị zijn drie zusters naar Tangkat om Orang kaja Brahim, die nog steeds in Langkat werd aangehouden, te zien.

Van Langkat ontving hij daama bericht, dat hij den Controleur in Pangkalan-Siata zou kumnen ontmoeten om over zijne aangelegenheden te spreken en had hij met dezen een onderhoud in de benting Salahhadji, waarbij Datoe Djohan verklaarde, dat hij wegens de gevangeneming van Orang kaja Brahim zeer verstoord was; dat hij den Pangéran niet wilde volgen en dat hij, als, onafhankelijk van Tamiang en van Langkat, zijn land sleehts aan het Gouvenement wilde overgeven. Daar Datoe Djohan verder mededeelde, dat hij de bewijzen voor zijn onafhankelijkheid in Tamiang zon kumnen krijgen, ging hij daarheen en moet toen werkelijk met brieven van Kedjoeroean Karang, Soetan Moeda en Radja Bandara naar Salahhadji zijn teruggekeerd, 
Van Salahhadji ging Datoe Djohan met de "Djohor" naar Deli, waar hij drie maanden verbleef en verder naar Bengkalis, waar hij na anderhalf jaar overleed. Hij was daar door het Gouvernement in ballingschap gehouden, aangezien men terechte vreesde dat, zoo -als de zaken stonden, zeker een botsing tusschen Datoe Djohan en het inlandsche bestuur van Langkat niet kon uitblijven.

$W_{i j}$ zullen hier alweder niet nagaan in hoever het inlandsche bestuur in Langkat zich onbillijk tegenover Datoe Djohan heeft gedragen en nog slechts melding maken van de aanstelling door den Pangéran van Lebei Bantah tot hoofd in Salahhadji van Orang kaja Koewang in Besitang en van Krani Akim in Pangkalan-Siata, waar later het hoofd-établissement van de Kali-anam Maatschappij was gevestigd.

Ten gevolge van den overval te Boekit Kramat in 1880 , waarbij één sergeant en 3 of 4 soldaten sneuvelden en eenige militairen nog werden verwond, werd Orang kaja Koewang ontzet en Iebei Bantah gedurende drie dagen op de kruisboot aangehouden en bleef dus Besitang zonder hoofd, totdat de zoon van Datoe Djohan na een kort verblijf te Bengkalis, met den gelar van Datoe Padoeka, tot hoofd in Besitang door den Pangéran werd aangesteld. Dit laatste had plaats in 1883.

De hiervoren beschreven gebeurtenissen hadden ten gevolge dat Salahhadji nagenoeg geheel werd verlaten; de peperplanters keerden naar hun land terug of legden nieuwe pepertuinen aan in de Serang djaija en Ajer-masin, waar thans nog op groote schaal de pepercultuur gedreven wordt. De eerste pepertuinen dagteekenen ook daar uit den tijd dat Datoe Djohan zich in Salahhadji vestigde. Deze zond den bovengenoemden Panglima moeda Semin naar de Serang djaija om pepertuinen aan te leggen en tegelijkertijd vestigde zich aan de Ajer masin-rivier een peperhoofd, die gelden van den Pangéran ontving. Zooals wij zagen, ontwikkelde zich hier de pepercultuur en nam het Atjehsch element onder de peperplanters een eerste plaats in. Thans zijn daar ongeveer 2000 Atjehers, die, uit alle streken van Atjeh afkomstig, daar een nagenoeg onaf hankelijk leven hebben. Zij gedragen zich daar over 't algemeen genomen rustig, doch blijven een factor, waarmede men rekening zal moeten houden, wanneer het de veiligheid van Langkat betreft.

Het was reeds, avond toen we op Pangkalan Siata terugkwamen, van waar wij den volgenden morgen een uitstapje maakten naar Salahhadji, aan de rivier van dien naam gelegen. 
Van Salahhadji keerden wij met een sampan terug naar Boekit Kramat en van daar met de stoombarkas naar Pangkalan Siata. Na van hieruit nog een tochtje gemaakt te hebben naar Toengkam, aan het riviertje van dien naam gelegen, vertrokken wij weder naar Tandjong Poera terug met den indruk, dat in deze onbewoonde streken nog een rijk veld openligt voor de ontwikkeling van industrie, zoowel wat de exploitatie van het hout als wat het ontginnen van gronden voor de tabakscultuur betreft.

Bengkalis, 19 Juli 1888. 